\title{
GAMBARAN PERESEPAN OBAT ANTIHIPERTENSI DI PUSKESMAS TELUK NIBUNG KOTA MADYA TANJUNG BALAI
}

\author{
Robiatun Rambe ${ }^{1}$, Nurhayati ${ }^{2}$ \\ ${ }^{1,2}$ Program Studi Farmasi, Fakultas Ilmu Kesehatan, Universitas Haji Sumatera Utara \\ Medan, Indonesia \\ Email: Marpaungnurhayati92@gmail.com \\ * corresponding author
}

\begin{abstract}
Abstrak
Hipertensi merupakan suatu keadaan seseorang mengalami peningkatan tekanan darah di atas normal yaitu tekanan darah sistolik. Hipertensi perlu mendapat penanganan, salah satunya penanganan antihipertensi dengan pemberian antihipertensi. Penelitian ini bertujuan untuk mengetahui Gambaran Peresepan Obat Antihipertensi di Puskesmas Teluk Nibung Kota Madya Tanjung Balai.Penelitian ini merupakan penelitian deskriptif. Penelitian ini telah dilaksanakan pada Juni 2020 sampai dengan Desember 2020. Populasi dalam penelitian ini adalah pasien hipertensi yang mendapat obat antihipertensi di Puskesmas Teluk Nibung sebanyak 483 orang pada tahun 2020. Pengambilan sampel menggunakan Simple sampling sampling yang ditentukan berdasarkan rumus Slovin sebanyak 83 orang. Hasil Penelitian didapat bahwa Obat antihipertensi yang tersedia di Puskesmas Teluk Nibung Kota Madya Tanjung Balai adalah Amlodipine $10 \mathrm{mg}$, Captopril 12,5 mg dan Captopril $25 \mathrm{mg}$, Penggunaan Obat Antihipertensi yang paling sering diresepkan di Puskesmas Teluk Nibung Kota Madya Tanjung adalah Amlodipine $10 \mathrm{mg}$. Saran dalam penelitian ini diharapkan dengan adanya penelitian ini Puskesmas Teluk Nibung Kota Madya Tanjung Balai terus berkontribusi memberikan pengobatan kepada masyarakat khususnya penyakit hipertensi untuk mencegah terjadinya komplikasi penyakit.
\end{abstract}

Kata kunci: Hipertensi, Pasien Hipertensi, Gambaran Penggunaan Antihipertensi

\begin{abstract}
Hypertension is a condition when a person has an increase in blood pressure above normal, namely systolic blood pressure. Hypertension needs to be treated, one of which is antihypertensive treatment by administering antihypertensives. This study aims to determine the description of the Prescription of Antihypertensive Drugs at the Teluk Nibung Health Center, Tanjung Balai Municipality. This research is descriptive research. This research was conducted from June 2020 to December 2020. The population in this study were 483 hypertensive patients who received antihypertensive drugs at Teluk Nibung Public Health Center in 2020. Sampling used simple sampling which was determined based on the Slovin formula as many as 83 people.The results showed that the antihypertensive drugs available at the Teluk Nibung Public Health Center, Kota Madya Tanjung Balai were Amlodipine $10 \mathrm{mg}$, Captopril $12.5 \mathrm{mg}$ and Captopril $25 \mathrm{mg}$. Suggestions in this study are expected that with this research, the Teluk Nibung Community Health Center, Tanjung Balai Municipality will continue to contribute to providing treatment to the community, especially hypertension to prevent disease complications.
\end{abstract}

Keywords: Hypertension, Hypertensive Patients, Description of Antihypertensive Use 


\section{Pendahuluan}

Hipertensi merupakan suatu keadaan seseorang mengalami peningkatan tekanan darah di atas normal yaitu tekanan darah sistolik $\geq 140 \mathrm{mmHg}$ dan atau tekanan darah diastolik $\geq 90 \mathrm{mmHg}$. Ada beberapa faktor yang dapat meningkatkan tekanan darah yaitu usia, jenis kelamin, keturunan (genetik), garam, stress, merokok, kehamilan, pil antihamil, hormon pria dan kortikosteroid. Semakin tinggi tekanan darah, semakin tinggi pula resiko terkena serangan jantung, stroke, dan penyakit ginjal (Ambarwati, 2019). Hipertensi perlu mendapat perhatian khusus dari masyarakat mengingat dampak yang ditimbulkan baik dalam jangka pendek maupun jangka panjang, salah satunya adalah upaya penanganan antihipertensi dengan terapi pemberian farmakologis antihipertensi secara tepat sebagai suatu langkah yang strategis (Putri dkk, 2019). Penatalaksanaan hipertensi dapat dilakukan dengan terapi non farmakologi (tanpa obat) dan terapi farmakologi (dengan obat). Terapi non farmakologi dengan melakukan modifikasi gaya hidup seperti menurunkan kelebihan berat badan, melakukan diet makanan yang diambil DASH (Dietary Approaches to Stop Hypertension), mengurangi asupan natrium, melakukan aktivitas fisik seperti aerobik, mengurangi konsumsi alkohol, dan menghentikan kebiasaan merokok. Sedangkan terapi farmakologi dengan menggunakan obat (Ambarwati, 2019).

Berdasarkan data obat antihipertensi yang tersedia di Puskesmas Teluk Nibung adalah amlodipine $10 \mathrm{mg}$, captopril 12,5 mg dan captopril $25 \mathrm{mg}$. Obat antihipertensi yang paling sering diresepkan di Puskesmas Teluk Nibung adalah Amlodipine $10 \mathrm{mg}$ dan Captopril $25 \mathrm{mg}$ (Profil Puskesmas Teluk Nibung, 2020).Berdasarkan permasalahan diatas peneliti tertarik ingin melakukan penelitian tentang "Gambaran Peresepan Obat Antihipertensi di Puskesmas Teluk Nibung Kota Madya Tanjung Balai”.

\section{Metode Penelitian}

Jenis penelitian ini merupakan penelitian deskriptif yaitu suatu metode yang digunakan untuk menggambarkan atau menganalisis suatu hasil penelitian tetapi tidak digunakan untuk membuat kesimpulan yang lebih luas,yaitu untuk melihat Gambaran Peresepan Obat Antihipertensi di Puskesmas Teluk Nibung Kota Madya Tanjung Balai.. Teknik pengambilan sampel menggunakan simple sampling. Penelitian ini telah dilaksanakan dari Juni 2020 sampai dengan Desember 2020. Populasi dalam penelitian ini adalah pasien hipertensi yang mendapat obat antihipertensi di Puskesmas Teluk Nibung sebanyak 483 orang pada tahun 2020.Untuk menghitung jumlah sampel pada penelitian ini menggunakan rumus slovin, dengan jumlah sampel sebanyak 83 orang. Data yang digunakan adalah data yang diperoleh dari rekam medik pasien rawat jalan hipertensi yang diberi informasi tentang jenis kelamin pasien, umur pasien, nama obat, golongan obat antihipertensi, dan dosis. Data yang diperoleh dianalisis secara deskriptif untuk mengetahui gambaran Peresepan Obat Antihipertensi pada pasien di Puskesmas Teluk Nibung Kota Madya Tanjung Balai yang meliputi golongan obat, dosis, dan kombinasi obat antihipertensi pada pasien hipertensi 


\section{Hasil dan Pembahasan}

Tabel 1. Karakteristika Responden di Puskesmas Teluk Nibung

\begin{tabular}{clcc}
\hline No & Karakteristik & Frekuensi (f) & Persentase (\%) \\
\hline 1 & Jenis Kelamin & 39 & \\
& Laki-Laki & 44 & 47,0 \\
& Perempuan & $\mathbf{8 3}$ & 53,0 \\
\hline & Jumlah & & $\mathbf{1 0 0 , 0}$ \\
\hline 1 & Umur Responden & 14 & 16,9 \\
& <50 Tahun & 30 & 36,1 \\
& 51-60 Tahun & 32 & 38,6 \\
& 61-70 Tahun & 7 & 8,4 \\
\hline >71 Tahun & Jumlah & $\mathbf{8 3}$ & $\mathbf{1 0 0 , 0}$ \\
\hline 2 & Pekerjaan & & 10,8 \\
& Wiraswasta & 9 & 42,2 \\
& Ibu Rumah Tangga/Tidak Bekerja & 35 & 28,9 \\
& Nelayan & 24 & 6,0 \\
& Karyawan Swasta & 5 & 12,1 \\
\hline & Pensiunan & 10 & $\mathbf{1 0 0 , 0}$ \\
\hline
\end{tabular}

Berdasarkan tabeldiatas dapat dilihat bahwa dari 83 orang pasien didapatkan sebagian besar berjenis kelamin perempuan sebanyak 44 orang (53\%), dengan frekuensi umur pasien sebagian besar adalah usia 61-70 tahun sebanyak 32 orang $(38,6 \%)$ dan pekerjaan pasien sebagian besar adalah sebagai Ibu Rumah Tangga/tidak bekerja sebanyak 35 orang $(42,2 \%)$.

Tabel 2. Obat Antihipertensi di Puskesmas Teluk Nibung Kota Madya Tanjung Balai

\begin{tabular}{cc}
\hline No & Nama Obat \\
\hline 1 & Amlodipine $10 \mathrm{mg}$ \\
\hline 2 & Captopril $12,5 \mathrm{mg}$ \\
\hline 3 & Captopril $25 \mathrm{mg}$ \\
\hline
\end{tabular}

Berdasarkan tabel diatas, dilihat bahwa obat antihipertensi yang tersedia di Puskesmas Teluk Nibung Kota Madya Tanjung Balai adalah Amlodipine 10 mg, Captopril 12,5 mg dan Captopril $25 \mathrm{mg}$.

Tabel 3. Distribusi Frekuensi Penggunaan Obat Antihipertensi di Puskesmas Teluk Nibung Kota Madya Tanjung Balai

\begin{tabular}{clcc}
\hline No & \multicolumn{1}{c}{ Obat Antihipertensi } & Frekuensi (f) & \% \\
\hline 1 & Amlodipine $10 \mathrm{mg}$ & 41 & 49,4 \\
2 & Captopril 12,5 mg & 17 & 20,5 \\
3 & Captopril 25 mg & 25 & 30,1 \\
\hline & Jumlah & $\mathbf{8 3}$ & $\mathbf{1 0 0}$ \\
\hline
\end{tabular}


Berdasarkan tabel 4.2 diatas dapat dilihat bahwa Penggunaan Obat Antihipertensi di Puskesmas Teluk Nibung Kota Madya Tanjung Balai yang paling sering diresepkan adalah Amlodipine $10 \mathrm{mg}$ sebanyak 41 kali diresepkan pada pasien hipertensi $(49,4 \%)$.

\section{Kesimpulan}

Berdasarkan penelitian yang dilakukan di Puskesmas Tangkahan Durian dapat disimpulkan bahwa obat antihipertensi yang tersedia di Puskesmas Teluk Nibung Kota Madya Tanjung Balai adalah Amlodipine $10 \mathrm{mg}$, Captopril 12,5 mg dan Captopril $25 \mathrm{mg}$ dan penggunaan Obat Antihipertensi yang paling sering diresepkan di Puskesmas Teluk Nibung Kota Madya Tanjung adalah Amlodipine $10 \mathrm{mg}$.

\section{Referensi}

Ambarwati. (2019). Pola Peresepan Obaat Antihipertensi pada Pasien Rawat Jalan di Poli Spesialis Penyakit Dalam RSUD Tidar Kota Magelang Periode Maret - Agustus 2018. Skripsi Universitas Setia Budi. Surakarta :

Black, J dan Hawks, J. (2014). Keperawatan Medikal Bedah: Manajemen Klinis untuk Hasil yang Diharapkan. Dialihbahasakan oleh Nampira R. Jakarta: Salemba Emban Patria.

Brunner \& Suddarth. (2014). Keperawatan Medikal Bedah. Edisi 8. Volume 2. Jakarta : EGC

Farida, U dan Cahyani. (2018). Pola Penggunaan Obat Antihipertensi pada Pasien Hipertensi Rawat Inap di RSUD Mardi Waluyo Blitar Bulan Juli-Desember Tahun 2016. Jurnal Wiyata. Volume 5. Nomor 1.

Hutagalung, S.T. (2019). Gambaran Penggunaan Resep Obat Antihipertensi Pasien Rawat Inap di RSUD Dr. Pirngadi Kota Medan. Karya Tulis Ilmiah. Poltekkes Kemenkes Medan.

Irianto Koes. (2014). Ilmu Kesehatan Masyarakat. Bandung: Alfabet.

Kementerian Kesehatan Republik Indonesia, 2018. Pusat Data dan Informasi tahun 2018. Jakarta :

Masriadi. (2016). Epidemiologi Penyakit Tidak Menular. Jakarta : TIM Syahrini, Erylna Nur., Susanto, Henry Setyawan., Udiyono, Ari. 2012 FaktorFaktor Risiko Hipertensi Primer di Puskesmas Tlogosari Kulon Kota Semarang. Jurnal Kesehatan Masyarakat. Vol 1, 2012: pp. 315 - 325.

Oktaviani, O. (2016). Metode Time Management terhadap Waktu Tunggu Pasien di Bagian Loket Pendaftaran di Puskesmas Bandarharjo Semarang Tahun 2016. Universitas Dian Nuswantoro.

Profil Dinas Kesehatan Sumatera Utara. (2016). Medan.

Profil Puskesmas Teluk Nibung. (2019). Tanjung Balai.

Putri, L. S. A, Satriyana, B. K dan Jawi, I, M. (2019). Gambaran Pola Penggunaan Obat Antihipertensi pada Pasien Hipertensi di Instalasi 
Rawat Inap RSUP Sanglah Denpasar Tahun 2016. Jurnal Medika Udayana, Volume 8 Nomor 6. ISSN : 2597-8012.

Saferi W, Andra., Mariza P, Yessie. (2013). KMB 2 :Keperawatan Medikal Bedah (Keperawatan Dewasa Teori dan Contoh Askep). Yogyakarta : Nuha Medika.

Sari, R. D. (2009). Evaluasi Peresepan Obat Antihipertensi Antara Pasien Umum dan Pasien Peserta Askes di Instalasi Rawat Jalan RSUP Dr. Sardjito Yogyakarta Bulan Januari - Juni 2008. Skripsi. Universitas Sanata Dharma. Yogyakarta :

Simatupang, G. (2019). Gambaran Peresepan Obat Antihipertensi Pasien Rawat Jalan di Puskesmas Sipahutar Kabupaten Tapanuli Utara. Karya Tulis Ilmiah. Poltekkes Kemenkes Medan.

Smeltzer \& Bare. (2012). Buku Ajar Keperawatan Medikal Bedah Brunner dan Suddarth (Ed.8, Vol. 1,2). Jakarta : EGC.

Supardi, S, Handayani, R, Herman, M.J, Raharni dan Leny. (2012). Kajian Perundang-Undangan Tentang Pemberian Informasi Obat dan Obat Tradisional di Indonesia. Jurnal Kefarmasian Indonesia. Volume 2. Nomor 1.

Tarigan, A.R., et al. (2018). Pengaruh Pengetahuan, Sikap dan Dukungan Keluarga Terhadap Diet Hipertensi di Desa Hulu Kecamatan Pancur Batu Tahun 2016. Jurnal Kesehatan. Vol.11 No.1 P-ISSN :2086-2555; E-ISSN: 2622-7363.

Wijaya, A.S dan Putri, Y.M. (2013). Keperawatan Medikal Bedah 2, Keperawatan Dewasa Teori dan Contoh Askep. Yogyakarta : Nuha Medika 